\title{
Computational fluid dynamics assessment of effect of different openings configurations on the thermal environment of a facility for coffee wet processing
}

\author{
Robinson Osorio Hernandez, ${ }^{1}$ Jairo Alexander Osorio Saraz, ${ }^{2}$ Keller Sullivan Oliveira, ${ }^{3}$ \\ Ivan Dario Aristizabal, ${ }^{2}$ Julio Cesar Arango ${ }^{2}$ \\ ${ }^{1}$ Departamento de Ingeniería Civil y Agrícola, Facultad de Ingeniería, Universidad Nacional de Colombia sede Bogotá, \\ Colombia; ${ }^{2}$ Departamento de Ingeniería Agrícola y Alimentos, Facultad de Ciencias Agrarias, Universidad Nacional de \\ Colombia sede Medellín, Colombia; ${ }^{3}$ Departamento de Engenharia Agrícola, Centro de Ciências Agrárias, \\ Universidade Federal de Viçosa, Viçosa-MG, Brasil
}

\begin{abstract}
This study aimed to analyze the effect of the area size and location of openings for natural ventilation on the temperature and relative humidity inside a typological facility for coffee wet processing that have been using in Colombia and some South America Countries as well, with mechanical drying inside, using modeling with computational fluid dynamics modeling, in order to find the best suitable condition for preserve the quality of the coffee parchment. A significant effect was found regarding the area and location of the openings for natural ventilation on the internal hygrothermal environment, but no significant effect was found on the temperature. It was also found that the chimney effect plays a decisive role in the mass transfer of water vapor and heat to the
\end{abstract}

Correspondence: Jairo Alexander Osorio Saraz, Departamento de Ingeniería Agrícola y Alimentos, Facultad de Ciencias Agrarias, Universidad Nacional de Colombia sede Medellín, Colombia.

Tel.: +57.3128089761.

E-mail: aosorio@unal.edu.co

Key words: Biological risk; hygrothermal environment; mechanical drying; post-harvest coffee.

Acknowledgements: this paper is part of the doctoral thesis titled: Environmental assessment and optimization of facilities for coffee processing of Robinson Osorio Hernandez. The authors thank the Universidad Nacional de Colombia, Universidade Federal de Viçosa, Federación Nacional de Cafeteros de Colombia, CNPq, and CAPES.

Contributions: the authors contributed equally.

Conflict interest: the authors declare no potential conflict of interest.

Received for publication: 23 July 2019.

Accepted for publication: 3 September 2019

${ }^{\circ}$ Copyright: the Author(s), 2020

Licensee PAGEPress, Italy

Journal of Agricultural Engineering 2020; LI:892

doi:10.4081/jae.2020.892

This article is distributed under the terms of the Creative Commons Attribution Noncommercial License (by-nc 4.0) which permits any noncommercial use, distribution, and reproduction in any medium, provided the original author(s) and source are credited. outside of the building, and helping to maintain a suitable internal environment for the preservation of coffee.

\section{Introduction}

Coffee is one of the most important beverages, behind petroleum, coffee is the world's second most valuable traded commodity (Garcia et al., 2014).

The post-harvest process and storage of coffee is one of the primary points for the preservation of coffee bean quality. It is estimated that the post-harvest process and storage affect more than $50 \%$ the quality of the final product (Carvajal et al., 2012; Clemente et al., 2015).

In regions like Colombia, Central America and Hawaii, Arabica coffees are processed via the wet method, and sun-dried or mechanically in order to reach a moisture content between $11-12 \%$; the coffee is dried in the interest of maintaining its quality and storing it for extended periods of time (Ciro et al., 2011; Ghosh et al., 2014; Wei et al., 2015). Otherwise, microbial contamination could occur in the cherries and during the harvesting, fermentation, drying and storage of coffee beans (Silva et al, 2008; Oliveros et al., 2013). Bacteria, yeasts and filamentous fungi have been reported in the pulp and coffee beans processed in Brazil, India, Hawaii, Congo, Argentina, Colombia, Costa Rica, Ethiopia and Mexico (Silva et al., 2008). Filamentous fungi predominate at the end of processing and during storage, with effects in terms of the flavor and aroma of the beverage, but fungi also present a safety risk to the final product, due to the production of toxic secondary metabolites, i.e. mycotoxins, which can be harmful to consumers at certain concentrations (Taniwaki et al., 2006; Paterson et al., 2014).

The indoor environment conditions of the place where parchment coffee is stored (warehouse of storage or facilities for processing of coffee) are very important. Fungi live and reproduce best between 70 to $80 \%$ relative humidity, whereas yeast and bacterial development require humidity higher than $85 \%$ in the intergranular air (Navarro et al., 2002). The biological risk is latent in facilities carrying out the wet processing of coffee; for instance, Aspergillus ochraceus was found in $70 \%$ of the facilities tested in Colombia, including coffee post-harvest facilities, solar dryers, coffee parchment and green coffee.

In the tropical zone, with temperatures higher than $27^{\circ} \mathrm{C}$ and relative humidity above $70 \%$, freshly harvested beans and processed grains could be attacked by insects common in storage (Navarro et al., 2002). 
In Colombia, approximately $70 \%$ of the volume of coffee is dried mechanically (Gonzalez et al., 2010; Osorio et al., 2016a). This process generates a lot of water vapor and heat into the facilities. In post-harvest coffee processing, the greatest power consumption occurs in the mechanical drying process, which has an efficiency of 50\% (Oliveros et al., 2013).

Natural ventilation is very important to improve indoor air quality and to reduce energy consumption in buildings, especially when the indoor temperature is close or higher than the temperature of the external environment (Wang et al., 2014; Aflaki et al., 2015). The strategic design of natural ventilation is often disregarded, since as there are not standards available to support designers in the project of natural ventilation openings in coffee facilities (Osorio et al., 2016a). The size and location of the openings for natural ventilation, and their correct orientation, are important factors to consider in the control of air streams (Ralegaonkar et al., 2010).

Design errors and poor control of coffee processing facilities can compromise the quality of the coffee beans due to an inadequate thermal environment (Osorio et al., 2016a). The bioclimatic approach of buildings in warm and wet tropical regions requires previous bioclimatic work, analyzing the envelope to limit the power contributions and optimize the flow of air from natural ventilation (Bastide et al., 2005).

The aim of this study was to analyze the effect of the area and the location of openings for natural ventilation on the temperature and relative humidity inside a typological facility for coffee wet processing in Colombia and some south America countries.

\section{Materials and methods}

This study was conducted in Antioquia State of Colombia, at coordinates $6^{\circ} 26^{\prime} 15^{\prime} \mathrm{N}, 75^{\circ} 19^{\prime} 50^{\prime} \mathrm{W}, 1700 \mathrm{~m}$ altitude, average temperature of $22^{\circ} \mathrm{C}$ (in November), in a typically facility for wet processing of coffee, oriented east-west, with a coffee cherry production of about $156250 \mathrm{~kg}$ year $^{-1}$ (31,250 kg year ${ }^{-1}$ of parchment coffee). The internal environment of the building was simulated for the month of November, during the main harvest of the year, which coincides with the second rainfall season in this part of Colombia (Oviedo et al., 2014), that is the most critical situation for operability conditions of the coffee buildings.

Figure 1 shows a geometry of installation for processing coffee. This facility has two floors (of equal size) in stepped form. On first floor is a mechanical drying area, and second floor is an area for pulped, fermented, and to classification of coffee. The dimensions of this building are: $5.50 \mathrm{~m}$ wide $\times 9.50 \mathrm{~m}$ long $\times 4 \mathrm{~m}$ high. The building has $15 \mathrm{~cm}$ of unplastered brick cladding (thermal conductivity $0.72 \mathrm{~W} . \mathrm{m} .{ }^{\circ} \mathrm{C}^{-1}$ ), with two windows on western side of $1.15 \mathrm{~m} \times 0.6 \mathrm{~m}$, and a window in roof discontinuity of $4.80 \mathrm{~m} \times$ $0.30 \mathrm{~m}$. The windows remain open all time (unglazed). The roof was made of fiber cement tiles (slope of roof $20 \%$, thermal conductivity $0.28 \mathrm{~W} \cdot \mathrm{m} .{ }^{\circ} \mathrm{C}^{-1}$ ).

The constant values input used in the simulations, corresponded to the most critical conditions during the day: the heat exchange drying machine uses coal (anthracite) as fuel, which, according to (Oliveros et al., 2013), has a consumption of $0.224 \mathrm{~kg}$ of coal per $\mathrm{kg}$ of dry parchment coffee, with a calorific value of $33440 \mathrm{~kJ} \mathrm{~kg}^{-1}$. The mechanical dryer of this building has a drying capacity of $1125 \mathrm{~kg}$ of parchment coffee per day. The mass flow of steam produced was average $0.05 \mathrm{~kg}$ of water. $\mathrm{sec}^{-1}$, and its temperature was $30^{\circ} \mathrm{C}$. Floor temperature was between $20-23^{\circ} \mathrm{C}$ and average out- door temperature was between $22-25^{\circ} \mathrm{C}$. For the air conditions the thermal conductivity of $0.02551 \mathrm{~W} . \mathrm{m} .{ }^{\circ} \mathrm{C}^{-1}$, and thermal diffusivity of $2.141 \times 10^{-5} \mathrm{~m}^{2} . \mathrm{s}^{-2}$ was assumed (Cengel, 2007).

Experimental data was obtained during four consecutive days. To collect temperature and relative humidity experimental data, 15 temperature sensors $\left(0.5^{\circ} \mathrm{C}\right.$ accuracy in the temperature range of $10{ }^{\circ} \mathrm{C}$ to $85^{\circ} \mathrm{C}$ ), and 15 relative humidity sensors (measuring range 0 to $100 \%, \pm 2 \%$ accuracy) were installed in this facility, as shown in Figure 1. Data on temperature and relative humidity were acquired by micro-controllers. The peak of production coincides with the rainy season, in which the sky remains cloudy (there is no direct solar radiation); for this reason, building surfaces temperature were taken with a thermal imaging (infrared) camera (measuring range $-20^{\circ} \mathrm{C}$ to $+1200^{\circ} \mathrm{C}, \pm 2^{\circ} \mathrm{C}$ or $2 \%$ accuracy).

The 3D geometry (1:1 scale) of the facility for coffee wet processing was developed in computational domain using a CAD tool. The geometry was then imported into software ANSYS ${ }^{\circledR}$ ICEM CFD (version 13) for development of a tetrahedral mesh consisting of 15,287 nodes and 74,514 elements (Figure 2) ), obtained after several refinements and mesh tests. When the geometries are complex, or the range of scale lengths is large (as in this case), a tetrahedral mesh is generally appropriate, which requires a smaller number of elements.

CFD-based computer models help with the visualization of scalar and vector fields of indoor environments by means of solving a set of equations that describe fluid flow, commonly known as the Navier-Stokes equations (Osorio et al., 2016b). Turbulence was modeled using the standard k- $\varepsilon$ turbulence method, which evaluates the viscosity $(\mu \tau)$ from a relationship between the turbulent kinetic energy $(\mathrm{k})$ and the turbulent kinetic energy dissipation (ع). It was used as a criterion to define solution convergence, i.e. a mean square error (MSE) of the smallest solution of $10^{-4}$.

The CFD simulation of the facility coffee carried out in the present work have the follows considerations: i) the steady state was used to validated the computational model with the experimental values; ii) incompressible flow; iii) turbulent flow; and iv) people heat flux was neglected.

The model that describes non-isothermal fluid flow is

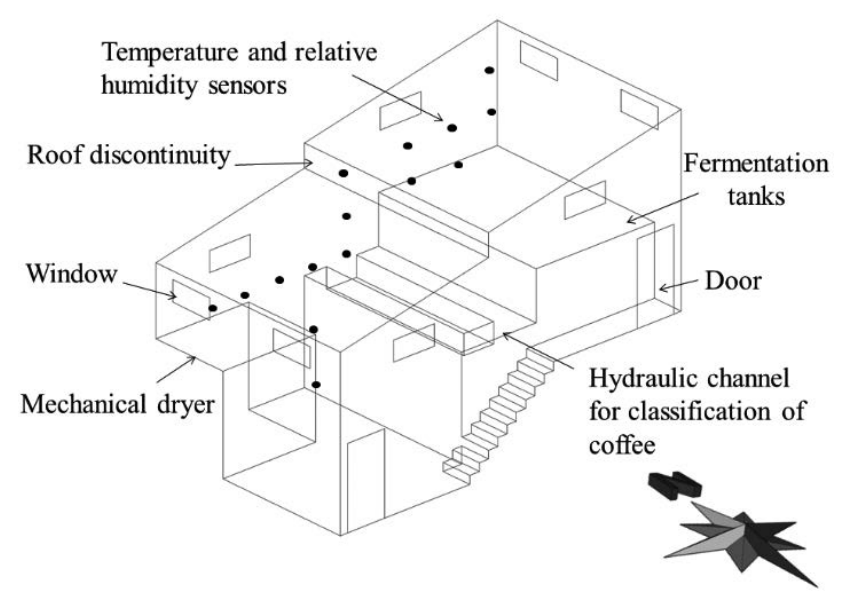

Figure 1. 3D geometry of the facility for wet processing of coffee. 
described by the simplified Equations (1, 2, 3 and 4) of mass, continuity, energy and species (Kim et al., 2008; Rocha et al., 2013), where: $C_{A}$ : concentration of species, $\mathrm{g} \mathrm{m}^{-3} ; C_{p}$ : specific heat, $\mathrm{W}$ $\mathrm{kg}^{-1} \mathrm{~K}^{-1} ; D$ : diffusion coefficient, $\mathrm{m}^{2} \mathrm{~s}^{-1} ; \rho$ : density, $\mathrm{kg} \mathrm{m}^{-3} ; k$ : thermal conductivity, $\mathrm{W} \mathrm{m}^{-1} \mathrm{~K}^{-1} ; \vec{m}$ : velocity component, $\mathrm{m} \mathrm{s}^{-1} ; T$ : temperature, $\mathrm{K}$; T: transposition operator; $U$ : velocity vector; $\mu_{\tau}$ : dynamic viscosity of the fluid, $\mathrm{kg} \mathrm{m}^{-1} \mathrm{~s}^{-1}$.

$$
\begin{gathered}
\nabla \cdot(\rho U)=0 \\
\nabla \cdot(\rho U U)=\nabla p+\left[\mu_{\tau}\left(\nabla U+\nabla U^{\mathrm{T}}\right)\right] \\
\nabla \cdot\left(-k \nabla T+\rho C_{p} T U\right)=0 \\
\vec{m} \cdot \nabla C_{A}=\nabla\left(D \nabla C_{A}\right)
\end{gathered}
$$

Different options for natural ventilation openings were simulated in order to determine the influence of vent area and the location of the openings on the temperature and relative humidity inside the facility. The different treatments can be seen in Figure 3. Treatment 1 (control) is the original geometry that was validated and simulated, while other treatments were different options of area and location of the openings for natural ventilation, including the use of a skylight of $1.0 \mathrm{~m} \times 1.0 \mathrm{~m}$ with an opening of $10 \mathrm{~cm}$ on the roof over the drying machine (treatments 8 and 9).

The results from the CFD model (T1 control) were verified and compared with the corresponding experimental measurements. Concordance between the measured values and those described by the CFD model were also evaluated, calculating the normal mean square error (NMSE) recommended by the American Society for Testing Materials (ASTM, 2002) (equation 5). For this, the average of the 15 points of temperature data and the 15 points of relative humidity data was calculated. Values with an NMSE less than 0.25 were accepted as good indicators of concordance; as this value approaches zero, the concordance between measured and predicted values is greater. For the statistical comparison of different treatments, a statistical analysis of variance $(\mathrm{P}<0.001)$ and post hoc test (Tukey, $\mathrm{P}<0.050$ ) was performed for the analysis of temperature and relative humidity.

$$
N M S E=\frac{1}{n} \sum_{i=1}^{n} \frac{\left(Y_{p i}-Y_{m i}\right)^{2}}{Y_{p i} Y_{m i}}
$$

where:

$Y_{p}$ predicted value

$Y_{m}$ : measured value

\section{Results and discussion}

A comparison between the data obtained by the model and the experimental data of the control treatment showed an NMSE of 0.0031 for temperature and 0.0025 for relative humidity, indicating good agreement between the results (Table 1). It was concluded that the proposed model can be used to accurately predict the behavior of temperature and relative humidity in the indoor facility.

Table 2 shows the average temperature data for the different

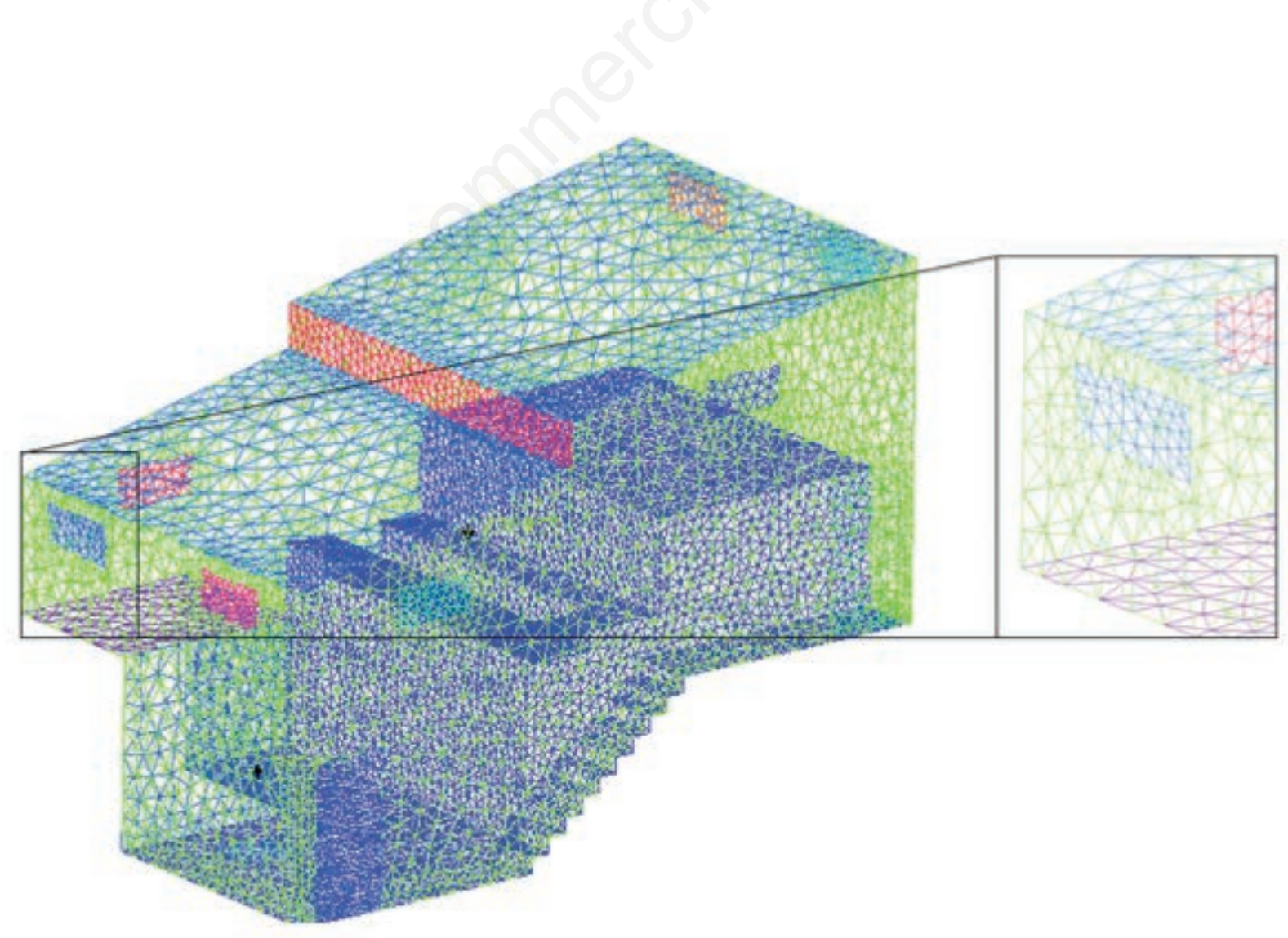

Figure 2. Building for coffee wet processing with a tetrahedral computational grid. 
treatments. It was found that increasing the vent area generated a slight fall in temperature in agree with the results found by Osorio et al. (2016b), as well as with the use of the skylight. All treatments have temperatures below $27^{\circ} \mathrm{C}$, that agree with Navarro et al. (2002) temperatures higher could generated attacked by insects on the grain. However, for the temperature, no differences were found among different treatments, in this case suggesting that there is little effect of the position of natural ventilation openings on the indoor temperature of the building, and ventilation area, as happening in the T4, T6, T7, T8 and T9, where the temperature is
Table 1. Comparison of experimental and modeled data for temperature and relative humidity of control treatment.

\begin{tabular}{|c|c|c|c|c|}
\hline & $\begin{array}{r}\text { Ind } \\
\text { temper }\end{array}$ & $\begin{array}{l}\text { air } \\
\text { ure }\left({ }^{\circ} \mathrm{C}\right)\end{array}$ & $\begin{array}{l}\text { Indoor } \\
\text { humidi }\end{array}$ & $\begin{array}{l}\text { elative } \\
\text { y (\%) }\end{array}$ \\
\hline & Experimental & CFD model & Experimental & CFD model \\
\hline Average & 26.1 & 26.2 & 90.1 & 90.3 \\
\hline NMSE & & & 0.002 & \\
\hline
\end{tabular}

CFD, computational fluid dynamics; NMSE, normal mean square error.

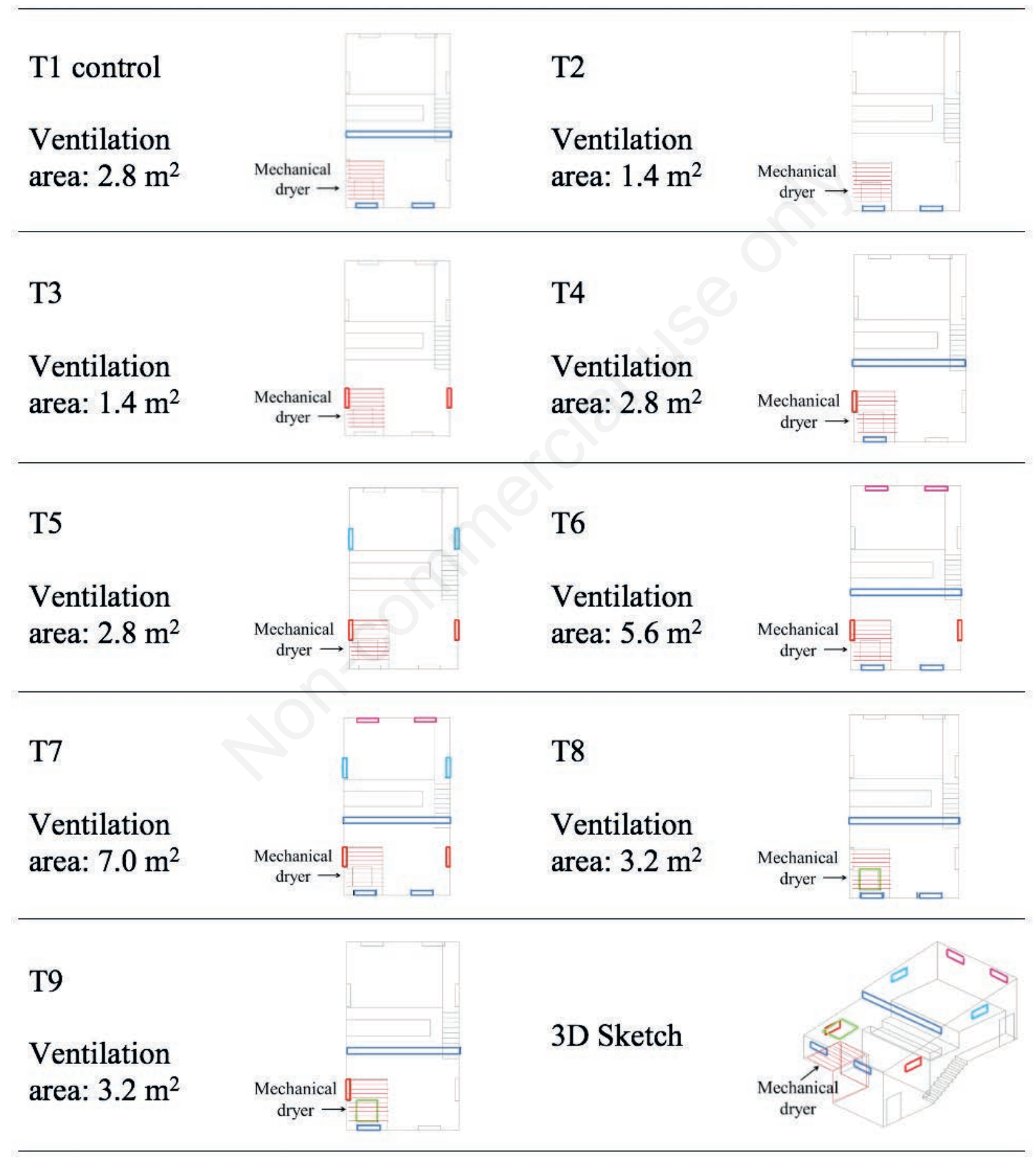

Figure 3. Architectural plants with different options of natural ventilation in terms of area and location of the openings. 
around $25^{\circ} \mathrm{C}$ and are lower that the temperature of the control $\mathrm{T} 1$, $\mathrm{T} 2, \mathrm{~T} 3$ and $\mathrm{T} 5$.

Table 3 shows the statistical analysis of relative humidity inside the facility. It was observed that there was a significant effect of the natural ventilation area on reducing the internal relative humidity. A statistically significant difference was found between treatments. This means that, besides the effect of natural ventilation area, the position of the natural ventilation openings, in this case, had a considerable effect, showing that when they were closer to the source of water vapor emission, the internal relative humidity decreased, as occurred in the T1, T4 and T5 treatments that have the same area but different positions.

On the other hand, in $\mathrm{T} 8$ and T9, the fact that the skylight was located on the same axis of the emission source of water vapor and heat (mechanical dryer), the proximity of other openings of the steam emission source, and the chimney effect (process by which air, when heated, becomes less dense and rises) played the most important role in the removal of water vapor, as a considerable decrease in the relative humidity and temperature was observed.

Under the bioclimatic conditions of T1, T2, T3, T5, T6 and T7 the biological risk was latent, as these conditions presented a relative humidity above $85 \%$, which can increase the risk of bacterial growth (Navarro et al.,2002).

The treatments T4, T8 and T9 presented conditions with lower relative humidity (mean of $75.9 \%$ ) than others ones, and this relative humidity could be constituting less risk to the final product, due to the production and proliferation of filamentous fungi which can adversely affect the quality of the final product, due to the production of toxic secondary metabolites, i.e. mycotoxins, which can be harmful to consumers at certain concentrations (Taniwaki et al., 2006; Paterson et al., 2014).

Figure 4 shows the profiles of temperature and relative humid-
Table 2. Statistical data of mean temperature $\left({ }^{\circ} \mathrm{C}\right)$.

\begin{tabular}{llllll} 
Treatment name & $\mathbf{N}$ & Mean & Max & Min & Std Dev \\
T1 control & 15 & $26.1^{\mathrm{a}}$ & 28.9 & 22.9 & 1.8 \\
T2 & 15 & $26.4^{\mathrm{a}}$ & 29.9 & 22.9 & 2.1 \\
\hline T3 & 15 & $26.3^{\mathrm{a}}$ & 29.9 & 23.9 & 1.8 \\
T4 & 15 & $25.3^{\mathrm{a}}$ & 28.9 & 22.9 & 1.7 \\
T5 & 15 & $26.3^{\mathrm{a}}$ & 29.9 & 22.9 & 2.0 \\
T6 & 15 & $25.6^{\mathrm{a}}$ & 28.8 & 21.8 & 2.0 \\
\hline T7 & 15 & $25.3^{\mathrm{a}}$ & 28.7 & 21.7 & 2.6 \\
T8 & 15 & $25.1^{\mathrm{a}}$ & 28.6 & 20.9 & 2.3 \\
\hline T9 & 15 & $25.2^{\mathrm{a}}$ & 28.7 & 20.9 & 2.4 \\
\hline
\end{tabular}

Std Dev, standard deviation. Means followed by the same letters do not differ by the Tukey's test at 0.05 . Probability ( $\mathrm{P}=0.036, \mathrm{~F}=2.157)$

Table 3. Statistical data of mean relative humidity (\%).

\begin{tabular}{llllll} 
Treatment name & NMeanMax & Min & Std Dev & \\
T1 control & 15 & $90.3^{\mathrm{a}}$ & 95.0 & 87.9 & 2.1 \\
T2 & 15 & $92.3^{\mathrm{a}}$ & 95.3 & 90.1 & 1.3 \\
\hline T3 & 15 & $92.9^{\mathrm{a}}$ & 95.5 & 92.2 & 1.0 \\
T4 & 15 & $75.9^{\mathrm{b}}$ & 94.0 & 68.9 & 7.9 \\
\hline T5 & 15 & $90.4^{\mathrm{a}}$ & 95.0 & 89.0 & 1.9 \\
T6 & 15 & $87.9^{\mathrm{c}}$ & 94.0 & 78.8 & 4.1 \\
\hline T7 & 15 & $86.9^{\mathrm{c}}$ & 93.5 & 75.9 & 4.6 \\
T8 & 15 & $58.9^{\mathrm{d}}$ & 61.1 & 58.1 & 0.8 \\
\hline T9 & 15 & $58.7^{\mathrm{d}}$ & 60.9 & 57.9 & 0.8 \\
\hline
\end{tabular}

Std Dev, standard deviation. Means followed by the same letters do not differ by the Tukey's test at 0.05 . Probability ( $\mathrm{P}=0.001, \mathrm{~F}=304.56)$.

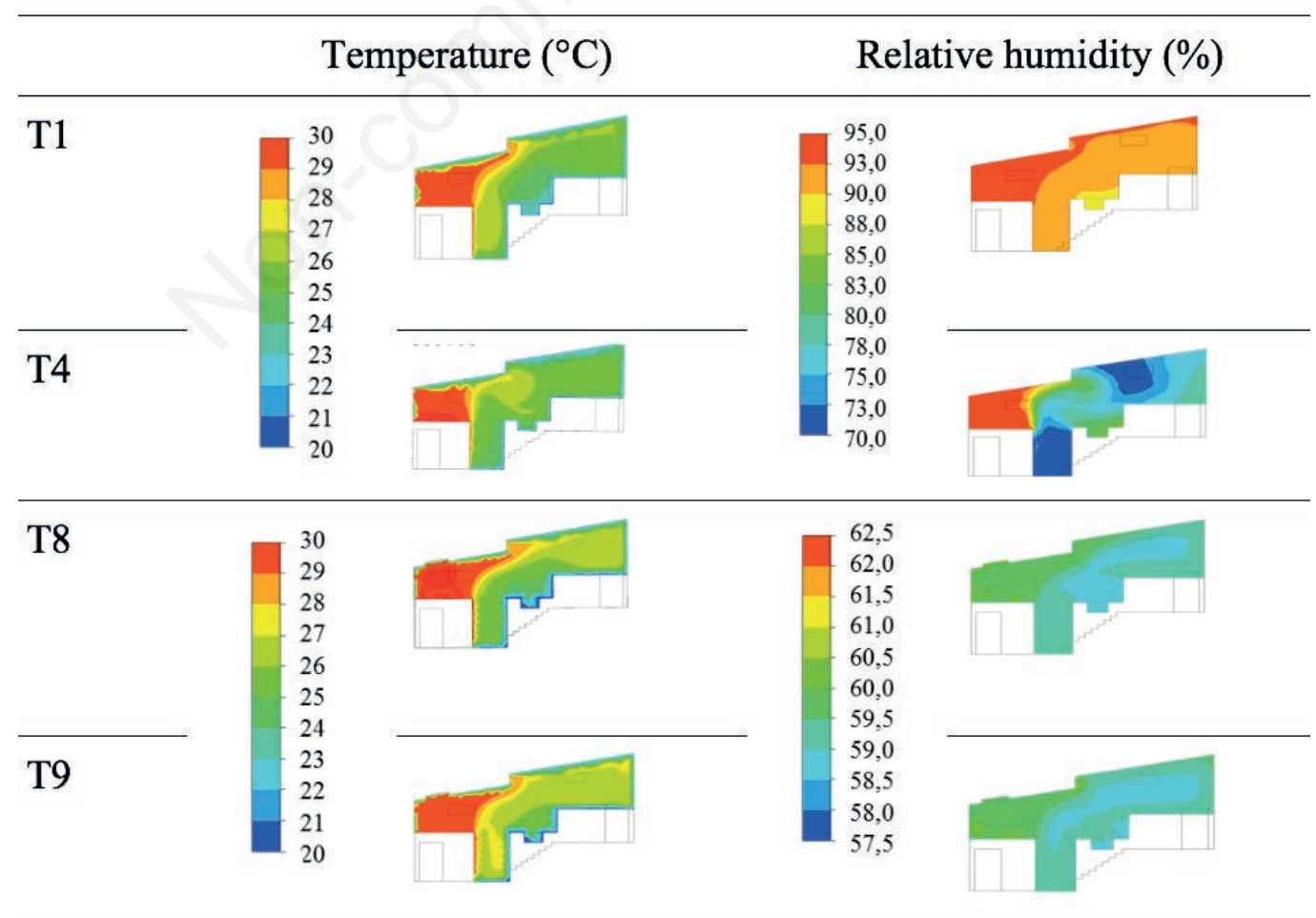

Figure 4. Computational fluid dynamics profiles of temperature and relative humidity of treatments T4, T8, T9 and T1 (control). 
ity inside the facility for treatments T1 (control treatment), T4 (two windows near the steam outlet of the drying machine), T8 (original configuration + skylight) and T9 (T4 configuration + skylight), that were the treatments that had lower relative humidity and temperature than other ones. It was observed that, in general, temperatures above $300.15^{\circ} \mathrm{K}\left(27^{\circ} \mathrm{C}\right)$, risking insect attack (Navarro et al., 2002; Taniwaki et al., 2006), occurred only near the vapor outlet of the drying machine in all treatments.

Moreover, Figure 4 shows that only the T1 configuration presents a relative humidity above $85 \%$ throughout its volume, moisture level that can increase the risk bacterial growth (Navarro et al., 2002). T4, T8 and T9 presented a relative humidity greater than $85 \%$, but only around the steam outlet of the coffee drying machine; in some areas, it presented a relative humidity between $70-85 \%$.

\section{Conclusions}

CFD modeling proved to be and useful tool for the bioclimatic analysis of facilities for coffee wet processing, where a significant effect of the natural ventilation area and position was observed in terms of reducing the relative humidity and temperature inside the typological facility investigated in this study, providing a suitable bioclimatic environment for preserving the quality of coffee.

T4, T8 and T9 treatments presented the best bioclimatic conditions, suggesting that make these changes in the buildings for coffee wet processing, as locating the openings close to emission sources of water vapor and heat, and increase the ventilation area, could improve conditions to preserve grain quality of this typology facility in Colombia and some south America countries.

\section{References}

Aflaki A., Mahyuddin N., Al-Cheikh Mahmoud Z., Baharum M. 2015. A review on natural ventilation applications through building facade components and ventilation openings in tropical climates. Energy Build. 101:153-62.

ASTM. 2002. American Society for Testing Materials, Guide for statistical evaluation of indoor air quality models (D5157-97); Accessed march 2 of 2017. Available from: https://users.encs. concordia.ca/ raojw/crd/reference/reference001858.html

Bastide A., Lauret P., Garde F., Boyer H. 2006. Building energy efficiency and thermal comfort in tropical climates. Presentation of a numerical approach for predicting the percentage of well-ventilated living spaces in buildings using natural ventilation. Energy Build. 38:1093-103.

Carvajal J., Aristizabal I., Oliveros C. 2012. Physical and mechanical properties evaluation of coffee fruit (Coffea arabica L. var. colombia) during its development and maturation. Dyna. 79:116-24

Cengel, Y. 2007. Heat transfer: a practical approach. McGraw-Hill, 840 pp.

Ciro H., Rodríguez M., Castaño J. 2011. Intermittent Coffee Drying in Deep Bed with Pulsed Airflow. Rev. Facult. Nacion. Agron. 64:6247-55.
Clemente C., Cirillo M., Malta M., Caixeta F., Pereira C., Da Rosa S. 2015. Post-harvest operations and physicochemical and sensory quality of coffees. Coffee Sci. 10:233-41.

Garcia J., Posada L.. Laderach P. 2014. Recommendations for the regionalizing of coffee cultivation in Colombia: A methodological proposal based on agro-climatic indices. PLoS One. 9:1-22.

Ghosh P., Venkatachalapathy N. 2014. Processing and Drying of Coffee - A Review. Int. J. Eng. Res. Technol. 3:784-94.

González C., Sanz J., Oliveros C. 2010. Control of flow and air temperature in the mechanical drying of coffee. Cenicafé. 61:281-96.

Kim K., Yoon J., Kwon H., Han J., Eek Son J., Nam S., Giacomelli G., Lee I. 2008. 3-D CFD analysis of relative humidity distribution in greenhouse with a fog cooling system and refrigerative dehumidifiers. Biosyst. Eng. 100:245-55.

Navarro S., Noyes R. 2002. The Mechanics And Physics Of Modern Grain Aeration Management. CRC Press, 672 pp.

Oliveros C., Peñuela A., Pabon J., Gravimet S.M. 2013. Technology to measure coffee moisture in drying in silos. Cenicafé. 433:1-8.

Osorio R., Guerra L., Tinôco I., Osorio J., Aristizábal I. 2015. Simulation of a thermal environment in two buildings for the wet processing of coffee. Dyna. 82:214-20.

Osorio R., Guerra L., Tinôco I., Martins J., Osorio J. 2016 a. Simulation of the internal environment of a post- C. D. F. harvest installation and a solar dryer of coffee. Rev. Bras. Eng. Agríc. Ambient. 20:163-8.

Osorio J., Tinôco I., Rocha K., Mendes L., Norton T. 2016 b. A CFD based approach for determination of ammonia concentration profile and flux from poultry houses with natural ventilation. Rev. Facult. Nacion. Agron. 69:1-10.

Oviedo N., Torres A. 2014. Water attenuation and hydrological benefits due to the implementation of ecoproductive green roofs in marginalized urban areas. Ing. Univ. 18:291-308.

Paterson R., Lima N., Taniwaki M. 2014. Coffee, mycotoxins and climate change. Food Res. Int. 61:1-15.

Ralegaonkar R., Gupta R. 2010. Review of intelligent building construction: A passive solar architecture approach. Renew. Sustain. Energy Rev. 14:2238-42.

Rocha K., Martins J., Martins M., Osorio J., Lacerda Filho A. 2013. Three-dimensional modeling and simulation of heat and mass transfer processes in porous media: an application for maize stored in a flat bin. Dry. Technol. 30:1099-106.

Silva C., Batista L., Schwan R. 2008. Incidence and Distribution of Filamentous Fungi During Fermentation, Drying and Storage of Coffee (Coffea arabica L.) Beans. Braz. J. Microbiol. 39:521-6.

Taniwaki M. 2006. An update on ochratoxigenic fungi and ochratoxin A in coffee. Adv. food Mycol. 571:189-202.

Wang Y., Zhao F., Kuckelkorn J., Liu D., Liu J., Zhang J. 2014. Classroom energy efficiency and air environment with displacement natural ventilation in a passive public school building. Energy Build. 70:258-70.

Wei L., Wai M., Curran P., Yu B., Quan S. 2015. Coffee fermentation and flavor - An intricate and delicate relationship. Food Chem. 185:182-91. 